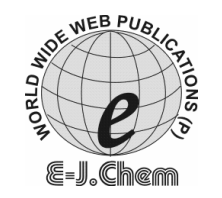

http://www.e-journals.net
ISSN: 0973-4945; CODEN ECJHAO

E-Journal of Chemistry

Vol. 5, No.3, pp. 607-619, July 2008

\title{
Interpretation of Groundwater Quality Using Multivariate Statistical Technique in Moradabad City, Western Uttar Pradesh State, India
}

\author{
J.K. PATHAK ${ }^{*}$, MOHD ALAM and SHIKHA SHARMA \\ Hydrobiology Lab, P.G. Department of Zoology, \\ University of Rohilkhand, Hindu College, Moradabad, 244001, India. \\ jugal28@yahoo.com
}

Received 15 November 2007; Revised 20 January 2008; Accepted 10 February 2008

\begin{abstract}
Groundwater samples from Moradabad city were analyzed for chemical parameters. For present study 58 water samples were collected from different localities on the basis of various land use patterns. The higher values of most of the parameters were found in the area of old settlement, while lower values observed in new settlements. This shows clear impact of land use on groundwater. Water quality data collected from different localities are used in conjunction with multivariate statistical technique to identify key variables. The first four components were chosen for interpretation of the data, which accounts for $77.38 \%$ of the total variance in the data set. The maximum number of variables, i.e. $\mathrm{Cl}, \mathrm{Na}, \mathrm{TH}, \mathrm{TDS}, \mathrm{EC}$ and salinity were characterized by first component, while second component is characterized by $\mathrm{DO}$ and $\mathrm{Mg}$. The third and fourth components were characterized by $\mathrm{Ca}, \mathrm{SiO}_{2} \mathrm{HCO}_{3}$ and $\mathrm{K}$ respectively. This shows that hydrochemical constituents of the groundwater are mainly controlled by TDS and EC. For cluster analysis single linkage method was used. The findings of the cluster analysis are presented in the form of dendrogram of the sampling stations (cases) as well as hydrochemical variables, which produced four major groupings, suggests that groundwater monitoring can be consolidated.
\end{abstract}

Keywords: Moradabad, Groundwater, Multivariate analysis, Cluster analysis, Hydrogeochemical

\section{Introduction}

Groundwater is the main source of potable water of Moradabad City. A number of people have installed water purifier in their houses in order to get rid off any contamination in water. The main source of groundwater contamination is from domestic and a number of electroplating industries, pulp and paper industry, dairy industry and sugar industry etc. These industries pour their effluents directly into open drain, unlined earthen drain and open pits in several places from where polluted water percolates into soil and finally reaches the aquifers. In India, research on the qualitative studies of groundwater specially with reference 
to fluoride has been carried out by various workers ${ }^{1,2}$. Due to limited and confined study of groundwater, interpretations of the quality of groundwater in the area are incomplete for taking any measure for sustainable development ${ }^{3}$.

The quality of water is depleting rapidly with the change in human life style i.e., massive industrialization, construction activities, utilization of agricultural land and forest land for other developmental purposes. Most of the groundwater studies focus on the assessment of quantitative sources and on the identification recharge processes. These developmental activities generate large quantities of concentrated effluents. These effluents are either dumped into ground or drain into open unlined earthen canals from where they percolate, resulting groundwater pollution.

The rapid industrialization and expansion of cities poses high pressure on water resources including groundwater, results their depletion and contamination. Therefore, it is necessary to monitor and evaluate water quality on regular basis. In present study, at certain places various parameters exceeds the WHO / Indian standards of potable water. Water quality of 58 sampling stations has been statistically researched by using multivariate technique. In this article factor analysis and cluster analysis are used to categorize the spatial variation.

\section{Study area}

Moradabad city is also known as Brass City of India having a number of export houses and a number of large and small scale electroplating industries. Moradabad is situated at a distance of $167 \mathrm{~km}$ from the national capital, New Delhi (NH 24), on the bank of river Ramganga and located at $28.83^{\circ} \mathrm{N} 78^{\circ} \mathrm{E}$. It has an average elevation of 186 meters (610 feet) above sea level. The city of Moradabad is inhabited on the alluvial deposits of quart energy period. The alluvial deposits has been drained and transported from Himalayan ranges by the river Ganga system and specially the River Ramganga. The texture of these deposits is from silt to sandy. These alluvial deposits are of two types; 1. Banger 2. Khaddar. Banger is referred to older alluvium and is found at remote areas from the river valley and at the surface that is loamy. The sand layer of Banger serve as aquifer at various depths from the ground. The Khaddar is newer deposits and found near and along the valley and is inundated every year by floods.

The alluvial loose deposits are laid on hard Paleogene rocks and these rocks are laid on Precambrian basement. The marine Paleogene sediment was deposited in a depression on western U.P. The Neogene sedimentary rocks found under the Ganga valley of nearby areas are totally absent under the quaternary alluvial deposits below Moradabad city. The Paleogene sedimentary rocks are situated at greater depths and much below the reach of general boreholes for tube well purposes in Moradabad city. The rock constitutes a small massif under quaternary deposits and is faulted toward east ${ }^{4}$. The underground water stored in sand layers and aquifers are found above these rocks and are used for all purposes in the city and nearby areas.

\section{Experimental}

In order to select suitable sampling sites, a preliminary survey was conducted to determine various land use patterns. On the basis of survey, 58 sampling sites are selected having previously installed jet pumps (we could not install any additional borehole pump due to paucity of funds and limitations with the authors) for groundwater analysis (Table 1). Samples are collected in sterilized polyethylene bottles of one liter and brought to well equipped laboratory for various chemical analysis. The physico-chemical parameters are analyzed with the help of Boush \& Lomb Spectrophotometer Spectronic-120, Systronics105, 
Hanna Pocket TDS meter, Hanna pocket pH meter, Century Flame Photometer, Century water testing kit and Centaury turbidity meter and conductivity meter. The selected parameters for the estimation of groundwater quality characteristics are: Total Dissolved Solids (TDS), Total Hardness (TH), Electrical Conductivity (EC), Carbon Dioxide $\left(\mathrm{CO}_{2}\right)$, Dissolved Oxygen (DO) Hydrogen-ion Concentration $(\mathrm{pH})$, Bicarbonate alkalinity $\left(\mathrm{HCO}_{3}\right)$, Calcium $(\mathrm{Ca})$, Magnesium $(\mathrm{Mg})$, Sodium $(\mathrm{Na})$, Potassium $(\mathrm{K})$, Silicate silica $\left(\mathrm{SiO}_{2}-\mathrm{Si}\right)$, and Salinity $(\mathrm{Sal})$. The parameters are analyzed as given in instrument manual and $\mathrm{APHA}^{5}$, Trivedy et al. ${ }^{6}$ Golterman et al. ${ }^{7}$, Goldman and Horne ${ }^{8}$, Welch ${ }^{9}$ and Weaver et $a l^{10}$. Before collecting water samples hand pumps and jet pumps were run continuously for some time to avoid any turbidity in water due to presence of fine mud and sand particles.

Table 1. Location of sampling stations (borehole location)

\begin{tabular}{|c|c|c|c|}
\hline Borehole No. & Location/Area & Borehole No. & Location/Area \\
\hline 1. & Gandhi Nagar & 2. & Idhagh \\
\hline 3. & Lajpat Nagar & 4. & Kathgargh Beech \\
\hline 5. & Peerzada & 6. & Pachpera Mandir \\
\hline 7. & Gospak Ki Zarat & 8. & Indra Chowk \\
\hline 9. & Galshaheed Park & 10. & Ismaile Road \\
\hline 11. & Gulshan Nagar & 12. & Amroha Gate \\
\hline 13. & Mandi Chowk & 14. & Bazigaran Guriya Mohalla \\
\hline 15. & Mugalpura Kotwali & 16. & Govt. Inter College \\
\hline 17. & Jama Maszid & 18. & Barwalan Chowk \\
\hline 19. & Katghar Railway Station & 20. & Hafiz Banne Ki Puliya \\
\hline 21. & Langreh Ki Puliya & 22. & Asalatpura \\
\hline 23. & Hindu College & 24. & Reeti Street \\
\hline 25. & Kath Ki Puliya & 26. & Nai Srak Chowk \\
\hline 27. & Savita Sadan & 28. & Mufti Tola \\
\hline 29. & Lal Bagh Mandir & 30. & Chaurasi Ghanta Mandir \\
\hline 31. & Jhabbu Ka Nala & 32. & Nawabpura Sartaj \\
\hline 33. & Kisrol & 34. & Nagfani Chowki \\
\hline 35. & Daulat Bagh & 36. & Bangla Gaon Chowk \\
\hline 37. & Deputy Ganj & 38. & Baradari \\
\hline 39. & Nagar Nigam 1 & 40. & Nagar Nigam 2 \\
\hline 41. & Nagar Nigam 3 & 42. & Kanjari Sarai \\
\hline 43. & Chiryatola & 44. & Linepar \\
\hline 45. & Prem Nagar & 46. & Mansarower \\
\hline 47. & BudhiVihar II & 48. & Budhi Vihar I \\
\hline 49. & Court Road & 50. & Jigar Colony \\
\hline 51. & Jamaa Masjid Chowk & 52. & Karula Gali No.1 \\
\hline 53. & Karula Gali No.5 & 54. & Karooli Ki Puliya \\
\hline 55. & Zahid Nagar & 56. & Islam Nagar \\
\hline 57. & Rahmat Nagar Gali No. 1 & 58. & Seta Puri \\
\hline
\end{tabular}




\section{Multivariate analysis}

The data were prepared and processed in SPSS 11.0 and Statistica software in window XP. Descriptive statistics and Factor analysis were processed in SPSS where cluster analysis was prepared in statistica software. Factor analysis was used to understand the correlation structure of collected data and identified most important factors contributing the data structure ${ }^{11-13}$. For factor analysis Varimax and Kaiser Normalization rotation method was used ${ }^{14}$ and also used to find association between parameters so that the number of measured variable can be reduced. After obtaining correlation matrix and eigen values, factor loading were used to measure the correlation between variables and factors. These variables were then rotated by Varimax rotation technique to obtain new variability which is easy to interpret. Cluster analysis is also another data reduction method that was used to classify entities with similar properties. Multivariate statistical method encompassing cluster analysis, factor analysis, principal component analysis and discriminate analysis have been successfully used in hydrochemistry for many years ${ }^{15-17}$. Factor analysis was also used to find association between parameters so that the number of measured parameters can be reduced. Known associations were then used to predict unmeasured water quality parameters ${ }^{18}$. The method divides a large number of homogenous groups on the basis of their correlation structure. For cluster analysis single linkage method was used. In this method the distance between the clusters was determined by the distance of the two closest objects (nearest neighbor) in the different clusters.

\section{Results and Discussion}

The descriptive statistics of the analyzed water quality parameters are depicted in Table 2. Higher values of TDS, EC, $\mathrm{Na}, \mathrm{Cl}, \mathrm{SiO}_{2}$ and Salinity is recorded in sampling station (SS) 31, while hardness and $\mathrm{HCO}_{3}$ is found higher in SS 17 and other parameter like, $\mathrm{CO}_{2}, \mathrm{Ca}$ and $\mathrm{pH}$ is higher in SS 45,05 and 46, respectively. The lowest value of $\mathrm{HCO}_{3}, \mathrm{Cl}, \mathrm{Na}$, TDS, EC and salinity is observed in SS 47. It is interesting to note that higher values of most of the parameters are found in the area of old settlement, while lower values observed in new settlement (Table 3). This shows clear impact of land-use on groundwater.

Table 2. Descriptive statistics of groundwater

\begin{tabular}{|c|c|c|c|c|c|c|c|c|}
\hline Parameters & Unit & $\begin{array}{c}\text { No. Of } \\
\text { Samples }\end{array}$ & Minimum & Maximum & Mean & St. Error & SD & Variance \\
\hline DO & $\mathrm{mg} / \mathrm{L}$ & 58 & 2.40 & 6.50 & 4.51 & 0.13 & 1.036 & 1.07 \\
\hline $\mathrm{CO}_{2}$ & $\mathrm{mg} / \mathrm{L}$ & 58 & 2.00 & 48.00 & 18.24 & 1.10 & 8.419 & 70.88 \\
\hline $\mathrm{HCO}_{3}$ & $\mathrm{mg} / \mathrm{L}$ & 58 & 98.00 & 630.00 & 307.48 & 16.04 & 122.18 & 14928.07 \\
\hline $\mathrm{Cl}$ & $\mathrm{mg} / \mathrm{L}$ & 58 & 14.20 & 256.70 & 107.39 & 8.67 & 66.05 & 4363.78 \\
\hline Hardness & $\mathrm{mg} / \mathrm{L}$ & 58 & 136.50 & 836.00 & 350.29 & 24.07 & 183.34 & 33615.05 \\
\hline $\mathrm{Ca}$ & $\mathrm{mg} / \mathrm{L}$ & 58 & 11.80 & 166.50 & 48.85 & 4.61 & 35.11 & 1233.31 \\
\hline $\mathrm{Mg}$ & $\mathrm{mg} / \mathrm{L}$ & 58 & 5.60 & 156.80 & 51.59 & 4.58 & 34.95 & 1221.90 \\
\hline $\mathrm{Na}$ & $\mathrm{mg} / \mathrm{L}$ & 58 & 28.00 & 140.00 & 76.17 & 3.10 & 23.63 & 558.39 \\
\hline $\mathrm{K}$ & $\mathrm{mg} / \mathrm{L}$ & 58 & 3.00 & 43.00 & 9.96 & 0.85 & 6.48 & 42.01 \\
\hline $\mathrm{SiO}_{2}$ & $\mathrm{mg} / \mathrm{L}$ & 58 & 10.00 & 20.00 & 17.03 & 0.31 & 2.39 & 5.71 \\
\hline TDS & $\mathrm{mg} / \mathrm{L}$ & 58 & 292.00 & 1898.00 & 902.53 & 50.17 & 382.14 & 146031.90 \\
\hline $\mathrm{EC}$ & $\mu \mathrm{S} / \mathrm{cm}$ & 58 & 372.00 & 2112.00 & 1086.03 & 57.65 & 439.11 & 192823.12 \\
\hline $\mathrm{pH}$ & - & 58 & 6.80 & 7.90 & 7.32 & 0.03 & 0.25 & 0.06 \\
\hline Salinity & $\mathrm{mg} / \mathrm{L}$ & 58 & 0.17 & 1.07 & 0.52 & 0.0302 & 0.22978 & 0.053 \\
\hline
\end{tabular}


Table 3. Chemical composition of groundwater from different localities of Moradabad city

\begin{tabular}{|c|c|c|c|c|c|c|c|c|c|c|c|}
\hline SS & DO $\mathrm{CO}_{2}$ & $\mathrm{CO}_{3}$ & $\mathrm{Cl}$ & $\mathrm{TH}$ & $\mathrm{Ca}$ & $\mathrm{Mg}$ & $\mathrm{Na}$ & $\mathrm{K}$ & $\mathrm{SiO}_{2}$ & TDS & $\mathrm{EC}$ \\
\hline 1 & 6.0612 .00 & 366.00 & 76.60 & 298.80 & 116.1 & 23.90 & 67.00 & 18.0 & 18.00 & 789.00 & 1064.0 \\
\hline 2 & 2.4212 .00 & 272.00 & 153.2 & 284.00 & 75.70 & 5.600 & 97.00 & 12.0 & 16.00 & 848.00 & 1169.0 \\
\hline 3 & 5.2514 .00 & 348.00 & 66.70 & 138.00 & 55.50 & 44.30 & 72.00 & 12.0 & 18.00 & 689.00 & 958.00 \\
\hline 4 & 4.4414 .00 & 226.00 & 116.3 & 218.40 & 87.50 & 18.90 & 62.00 & 11.0 & 16.00 & 665.00 & 908.00 \\
\hline 5 & 4.8412 .00 & 290.00 & 170.2 & 415.80 & 166.5 & 35.20 & 92.00 & 14.0 & 12.00 & 1184.0 & 1729.0 \\
\hline 6 & 4.4432 .00 & 504.00 & 146.1 & 344.40 & 137.9 & 45.80 & 94.00 & 11.0 & 18.00 & 1190.0 & 1624.0 \\
\hline 7 & 5.2518 .00 & 248.00 & 256.7 & 407.40 & 163.2 & 46.00 & 82.00 & 11.0 & 18.00 & 1265.0 & 1702.0 \\
\hline 8 & 6.466 .000 & 216.00 & 92.19 & 154.40 & 62.20 & 31.40 & 67.00 & 12.0 & 18.00 & 671.00 & 896.00 \\
\hline 9 & 5.6520 .00 & 294.00 & 170.2 & 273.00 & 109.3 & 56.40 & 99.00 & 10.0 & 14.00 & 1182.0 & 1563.0 \\
\hline 10 & 4.8420 .00 & 406.00 & 165.5 & 310.00 & 124.5 & 52.00 & 80.00 & 12.0 & 16.00 & 1094.0 & 1470.0 \\
\hline 11 & 6.0614 .00 & 436.00 & 120.1 & 172.20 & 68.90 & 68.30 & 93.00 & 12.0 & 12.00 & 1040.0 & 1402.0 \\
\hline 12 & 4.8424 .00 & 214.00 & 59.60 & 136.50 & 54.70 & 42.80 & 95.00 & 12.0 & 14.00 & 708.00 & 858.00 \\
\hline 13 & 5.7026 .00 & 374.00 & 82.30 & 476.00 & 25.20 & 100.8 & 93.00 & 11.0 & 20.00 & 923.00 & 1104.0 \\
\hline 14 & 4.8030 .00 & 272.00 & 107.8 & 514.00 & 56.30 & 91.00 & 94.00 & 7.00 & 19.00 & 1066.0 & 1326.0 \\
\hline 15 & 6.5024 .00 & 250.00 & 171.6 & 836.00 & 77.40 & 156.8 & 90.00 & 5.00 & 18.00 & 1404.0 & 1705.0 \\
\hline 16 & 5.6016 .00 & 442.00 & 97.80 & 526.00 & 37.80 & 105.3 & 88.00 & 9.00 & 19.00 & 940.00 & 1142.0 \\
\hline 17 & 4.8018 .00 & 630.00 & 76.60 & 562.00 & 42.00 & 111.5 & 90.00 & 38.0 & 18.00 & 1202.0 & 1139.0 \\
\hline 18 & 6.0618 .00 & 616.00 & 163.1 & 712.00 & 29.40 & 155.8 & 116.0 & 10.0 & 18.00 & 1335.0 & 785.00 \\
\hline 19 & 5.3020 .00 & 410.00 & 63.80 & 490.00 & 26.90 & 103.1 & 81.00 & 6.00 & 19.00 & 864.00 & 1625.0 \\
\hline 20 & 5.6024 .00 & 224.00 & 180.1 & 700.00 & 60.60 & 133.9 & 107.0 & 10.0 & 20.00 & 1384.0 & 1046.0 \\
\hline 21 & 6.5026 .00 & 396.00 & 177.3 & 504.00 & 31.90 & 103.5 & 126.0 & 17.0 & 20.00 & 1202.0 & 1670.0 \\
\hline 22 & 4.8016 .00 & 352.00 & 56.70 & 412.00 & 18.50 & 89.30 & 86.00 & 8.00 & 18.00 & 790.00 & 958.00 \\
\hline 23 & 6.5014 .00 & 320.00 & 44.00 & 292.00 & 35.50 & 49.80 & 75.00 & 10.0 & 16.00 & 639.00 & 876.00 \\
\hline 24 & 3.2012 .00 & 230.00 & 87.93 & 356.00 & 35.30 & 35.30 & 75.00 & 6.00 & 18.00 & 866.00 & 997.00 \\
\hline 25 & 2.4016 .00 & 334.00 & 80.84 & 300.00 & 23.60 & 23.60 & 74.00 & 7.00 & 20.00 & 773.00 & 878.00 \\
\hline 26 & 4.0024 .00 & 264.00 & 234.0 & 748.00 & 52.10 & 52.10 & 97.00 & 10.0 & 20.00 & 1732.0 & 1938.0 \\
\hline 27 & 4.8026 .00 & 328.00 & 209.9 & 712.00 & 43.70 & 43.70 & 83.00 & 8.00 & 16.00 & 1631.0 & 1860.0 \\
\hline 28 & 3.6026 .00 & 292.00 & 222.7 & 744.00 & 37.00 & 37.00 & 91.00 & 7.00 & 18.00 & 1612.0 & 1860.0 \\
\hline 29 & 3.2012 .00 & 344.00 & 52.50 & 260.00 & 42.00 & 42.00 & 48.00 & 6.00 & 16.00 & 549.00 & 642.00 \\
\hline 30 & 4.8024 .00 & 312.00 & 255.3 & 568.00 & 68.90 & 68.90 & 109.0 & 7.00 & 16.00 & 1563.0 & 1761.0 \\
\hline 31 & 4.0028 .00 & 520.00 & 248.2 & 588.00 & 33.60 & 33.60 & 140.0 & 10.0 & 18.00 & 1898.0 & 2112.0 \\
\hline 32 & 4.8012 .00 & 256.00 & 35.50 & 224.00 & 48.80 & 48.80 & 93.00 & 8.00 & 20.00 & 475.00 & 573.00 \\
\hline 33 & 3.2024 .00 & 348.00 & 219.8 & 500.00 & 43.70 & 43.70 & 65.00 & 8.00 & 20.00 & 1371.0 & 1582.0 \\
\hline 34 & 3.608 .000 & 252.00 & 21.30 & 208.00 & 16.80 & 16.80 & 32.00 & 3.00 & 18.00 & 422.00 & 516.00 \\
\hline 35 & 4.4026 .00 & 328.00 & 80.80 & 328.00 & 25.20 & 25.20 & 63.00 & 6.00 & 18.00 & 724.00 & 848.00 \\
\hline 36 & 4.0012 .00 & 292.00 & 31.20 & 200.00 & 28.60 & 28.60 & 62.00 & 6.00 & 20.00 & 514.00 & 610.00 \\
\hline 37 & 4.0042 .00 & 528.00 & 106.3 & 416.00 & 16.80 & 16.80 & 110.0 & 8.00 & 19.00 & 1154.0 & 1332.0 \\
\hline 38 & 4.8012 .00 & 320.00 & 85.10 & 380.00 & 11.80 & 11.80 & 77.00 & 6.00 & 18.00 & 894.00 & 1047.0 \\
\hline 39 & 4.406 .000 & 116.00 & 24.80 & 180.00 & 45.40 & 45.40 & 43.00 & 6.00 & 16.00 & 385.00 & 497.00 \\
\hline 40 & 4.046 .000 & 120.00 & 53.10 & 188.00 & 37.00 & 37.00 & 59.00 & 7.00 & 20.00 & 512.00 & 648.00 \\
\hline 41 & 3.2014 .00 & 160.00 & 56.70 & 320.00 & 43.70 & 43.70 & 71.00 & 8.00 & 12.00 & 685.00 & 852.00 \\
\hline 42 & 4.8020 .00 & 170.00 & 53.10 & 296.00 & 23.50 & 23.50 & 64.00 & 10.0 & 14.00 & 694.00 & 880.00 \\
\hline 43 & 4.8018 .00 & 170.00 & 28.30 & 140.00 & 37.00 & 37.00 & 63.00 & 10.0 & 10.00 & 599.00 & 755.00 \\
\hline 44 & 4.0024 .00 & 150.00 & 116.3 & 340.00 & 63.90 & 63.90 & 65.00 & 6.00 & 16.00 & 784.00 & 983.00 \\
\hline
\end{tabular}




\begin{tabular}{lllllllllllll}
\hline 45 & 2.40 & 48.00 & 224.00 & 76.60 & 340.00 & 21.90 & 21.90 & 77.00 & 10.0 & 16.00 & 875.00 & 1105.0 \\
46 & 3.20 & 2.000 & 108.00 & 17.00 & 168.00 & 16.80 & 16.80 & 33.00 & 8.00 & 12.00 & 328.00 & 425.00 \\
47 & 4.80 & 4.000 & 98.000 & 14.20 & 160.00 & 31.90 & 19.56 & 28.00 & 6.00 & 16.00 & 292.00 & 372.00 \\
48 & 4.00 & 16.00 & 140.00 & 57.00 & 268.00 & 25.20 & 50.00 & 52.00 & 8.00 & 18.00 & 542.00 & 693.00 \\
49 & 4.8018 .00 & 220.00 & 35.50 & 232.00 & 21.00 & 43.80 & 30.00 & 6.00 & 20.00 & 444.00 & 530.00 \\
50 & 4.40 & 12.00 & 256.00 & 49.60 & 248.00 & 29.43 & 42.60 & 38.00 & 7.00 & 18.00 & 463.00 & 781.00 \\
51 & 4.2016 .00 & 560.00 & 106.4 & 440.00 & 26.90 & 90.90 & 75.00 & 43.0 & 16.00 & 1323.0 & 1483.0 \\
52 & 3.2016 .00 & 324.00 & 156.0 & 180.00 & 57.20 & 85.00 & 64.00 & 8.00 & 18.00 & 815.00 & 955.00 \\
53 & 4.80 & 22.00 & 412.00 & 141.8 & 256.00 & 18.50 & 51.20 & 77.00 & 12.0 & 16.00 & 1146.0 & 1124.0 \\
54 & 3.2012 .00 & 272.00 & 53.90 & 168.00 & 35.30 & 19.50 & 49.00 & 7.00 & 18.00 & 530.00 & 633.00 \\
55 & 4.4012 .00 & 244.00 & 92.20 & 168.00 & 25.20 & 25.60 & 56.00 & 10.0 & 16.00 & 554.00 & 686.00 \\
56 & 3.60 & 24.00 & 412.00 & 56.80 & 160.00 & 33.60 & 18.50 & 47.00 & 5.00 & 14.00 & 493.00 & 526.00 \\
57 & 4.0018 .00 & 380.00 & 140.4 & 172.00 & 25.20 & 26.60 & 78.00 & 9.00 & 16.00 & 896.00 & 964.00 \\
58 & 4.0016 .00 & 244.00 & 113.5 & 184.00 & 23.50 & 30.50 & 84.00 & 9.00 & 16.00 & 735.00 & 823.00 \\
\hline
\end{tabular}

SS-Sampling Stations; DO - Dissolved Oxygen; TH-Total Hardness as $\mathrm{CaCO}_{3}$; TDS - Total Dissolved Solids; EC-Electrical Conductivity, All parameters are in $\mathrm{mg} / \mathrm{L}$ except $\mathrm{pH}$ and $\mathrm{EC}(\mu \mathrm{S} / \mathrm{cm})$

Table 4 represents the initial eigen value, percent of variance and cumulative percent of total variance of groundwater data. From table 4, it is inferred that the first four components together account for $77.38 \%$ of the total variance in which the first component accounts for $40.66 \%$ of the total variance.

Table 4. Rotated component matrix, eigen value, percentage of total variance and cumulative percentage of groundwater

\begin{tabular}{ccccc}
\hline \multirow{2}{*}{ Variables } & \multicolumn{4}{c}{ Components } \\
\cline { 2 - 5 } & 1 & 2 & -0.133 & 4 \\
\hline $\mathrm{DO}$ & $6.677 \mathrm{E}-02$ & 0.865 & 0.407 & 0.109 \\
$\mathrm{CO}_{2}$ & 0.653 & -0.232 & 0.238 & 0.711 \\
$\mathrm{HCO}_{3}$ & 0.371 & 0.138 & -0.149 & $-4.861 \mathrm{E}-02$ \\
$\mathrm{Cl}$ & 0.922 & $8.296 \mathrm{E}-02$ & 0.344 & $3.442 \mathrm{E}-02$ \\
$\mathrm{Hardness}$ & 0.759 & 0.341 & -0.719 & $-7.556 \mathrm{E}-02$ \\
$\mathrm{Ca}$ & 0.401 & 0.220 & 0.328 & 0.237 \\
$\mathrm{Mg}$ & 0.287 & 0.739 & 0.109 & 0.252 \\
$\mathrm{Na}$ & 0.752 & 0.240 & -0.176 & 0.881 \\
$\mathrm{~K}$ & $8.360 \mathrm{E}-02$ & 0.136 & 0.620 & -0.182 \\
$\mathrm{SiO}$ & 0.140 & 0.303 & $4.432 \mathrm{E}-02$ & 0.195 \\
$\mathrm{TDS}$ & 0.943 & 0.138 & -0.121 & 0.123 \\
$\mathrm{EC}$ & 0.925 & 0.106 & -0.511 & -0.244 \\
$\mathrm{pH}$ & -0.589 & $-1.422 \mathrm{E}-02$ & $-5.646 \mathrm{E}-02$ & 0.277 \\
Salinity & 0.879 & 0.182 & 1.521 & 1.148 \\
Eigenvalue & 6.539 & 1.625 & 12.236 & 11.839 \\
Total variance & 40.663 & 12.646 & 65.545 & 77.384 \\
Cumulative \% & 40.663 & 53.309 &
\end{tabular}

The second component explains $12.64 \%$, the third component $12.23 \%$ and fourth component exhibit $11.83 \%$ of the total variance. Guidelines have been developed for determining the number of factors to be used and ignored ${ }^{19-22}$. For interpreting of the data the method of Kaiser Criterion ${ }^{23}$, is followed which retains only those factors having eigen values greater than 1 . The first four factors having an eigen value greater than 1 has been used for further interpretation. 
The extracted components explain nearly $77.38 \%$ of the variability in the original 14 variables. The number of eigen values can be estimated from a scree plot demonstrated in Figure 1. As shown in this figure, the eigen value sharply decrease within the first four components and then slowly stabilize for the remaining ones.

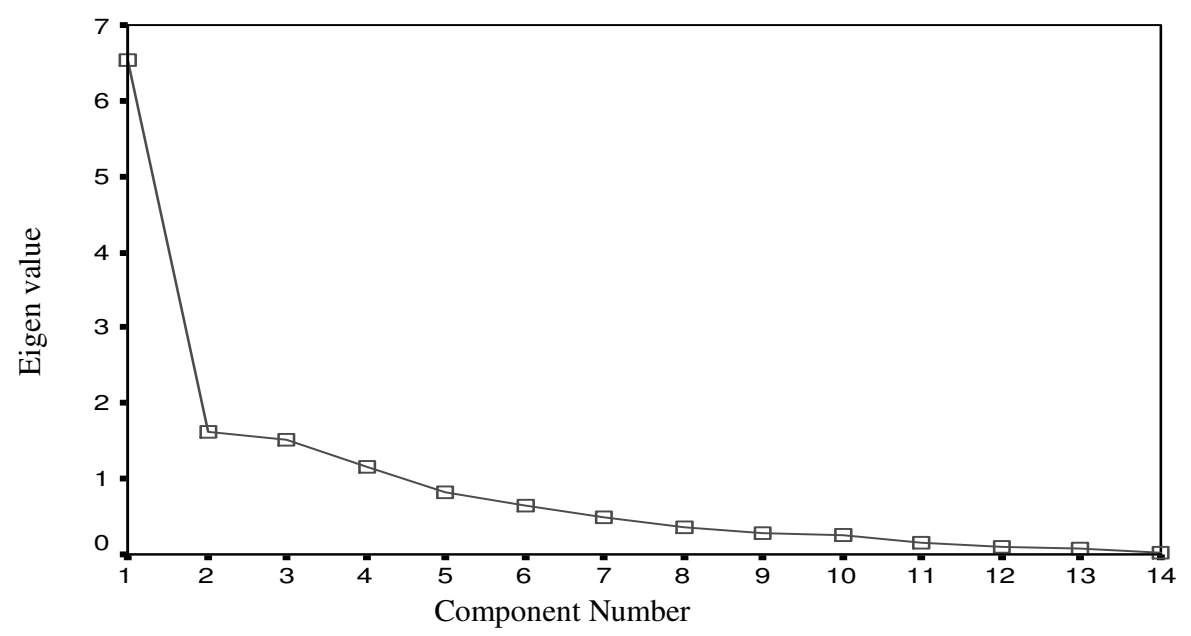

Figure 1. Scree plot of groundwater

The regression analysis between TDS-Salinity; TDS-EC; TDS - hardness; TDS - Cl; TDS - Na shows strong positive relationship as $\mathrm{r}=0.93,0.91,0.83,0.89$ and 0.77 , respectively, and moderate positive correlation with $\mathrm{Na}$ ions $(\mathrm{r}=0.77)$ and very low positive correlation ( $\mathrm{r}=0.29-0.56$ ) with $\mathrm{Ca}, \mathrm{Mg}, \mathrm{CO}_{2}$ and $\mathrm{HCO}_{3}$ suggesting the aquifer chemistry to be mainly controlled by TDS, Hardness, EC, $\mathrm{Cl}$ and Salinity (Table 5 and Figure 2-5).

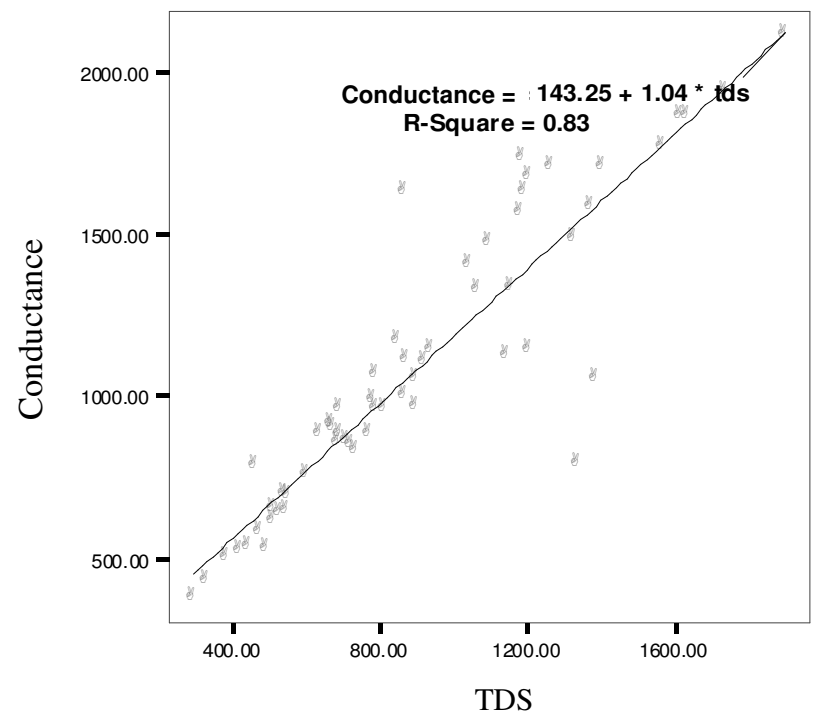

Figure 2. Correlation between total and dissolved solids (TDS and EC) 
Table 5. Correlation coefficient matrix of hydrochemical data of groundwater.

\begin{tabular}{|c|c|c|c|c|c|c|c|c|c|c|c|c|c|c|}
\hline & DO & $\mathrm{CO}_{2}$ & $\mathrm{HCO}_{3}$ & $\mathrm{Cl}$ & TH & $\mathrm{Ca}$ & $\mathrm{Mg}$ & $\mathrm{Na}$ & $\mathrm{K}$ & $\mathrm{SiO}_{2}$ & TDS & EC & $\mathrm{pH}$ & Salinity \\
\hline DO & 0.000 & & & & & & & & & & & & & \\
\hline $\mathrm{CO}_{2}$ & -0.038 & 0.000 & & & & & & & & & & & & \\
\hline $\mathrm{HCO}_{3}$ & 0.203 & 0.357 & 0.000 & & & & & & & & & & & \\
\hline $\mathrm{Cl}$ & 0.110 & 0.428 & 0.319 & 0.000 & & & & & & & & & & \\
\hline $\mathrm{TH}$ & 0.234 & 0.471 & 0.370 & 0.648 & 0.000 & & & & & & & & & \\
\hline $\mathrm{Ca}$ & 0.255 & 0.006 & 0.021 & 0.448 & 0.076 & 0.000 & & & & & & & & \\
\hline $\mathrm{Mg}$ & 0.536 & 0.191 & 0.376 & 0.262 & 0.616 & 0.039 & 0.000 & & & & & & & \\
\hline $\mathrm{Na}$ & 0.318 & 0.534 & 0.533 & 0.661 & 0.610 & 0.230 & 0.447 & 0.000 & & & & & & \\
\hline $\mathrm{K}$ & 0.175 & 0.015 & 0.496 & 0.090 & 0.132 & 0.130 & 0.261 & 0.234 & 0.000 & & & & & \\
\hline $\mathrm{SiO}_{2}$ & 0.062 & 0.158 & 0.214 & 0.137 & 0.356 & -0.179 & 0.268 & 0.161 & -0.074 & 0.000 & & & & \\
\hline TDS & 0.187 & 0.558 & 0.516 & 0.894 & 0.823 & 0.282 & 0.415 & 0.778 & 0.274 & 0.168 & 0.000 & & & \\
\hline $\mathrm{EC}$ & 0.208 & 0.528 & 0.423 & 0.844 & 0.700 & 0.432 & 0.290 & 0.713 & 0.232 & 0.103 & 0.909 & 0.000 & & \\
\hline $\mathrm{pH}$ & -0.064 & -0.650 & $0-0.431$ & -0.405 & -0.605 & 0.037 & -0.459 & -0.536 & -0.143 & -0.198 & -0.565 & -0.478 & 0.000 & \\
\hline Salinity & 0.201 & 0.467 & 0.484 & 0.837 & 0.763 & 0.346 & 0.460 & 0.683 & 0.393 & 0.109 & 0.934 & 0.868 & -0.513 & 0.000 \\
\hline
\end{tabular}




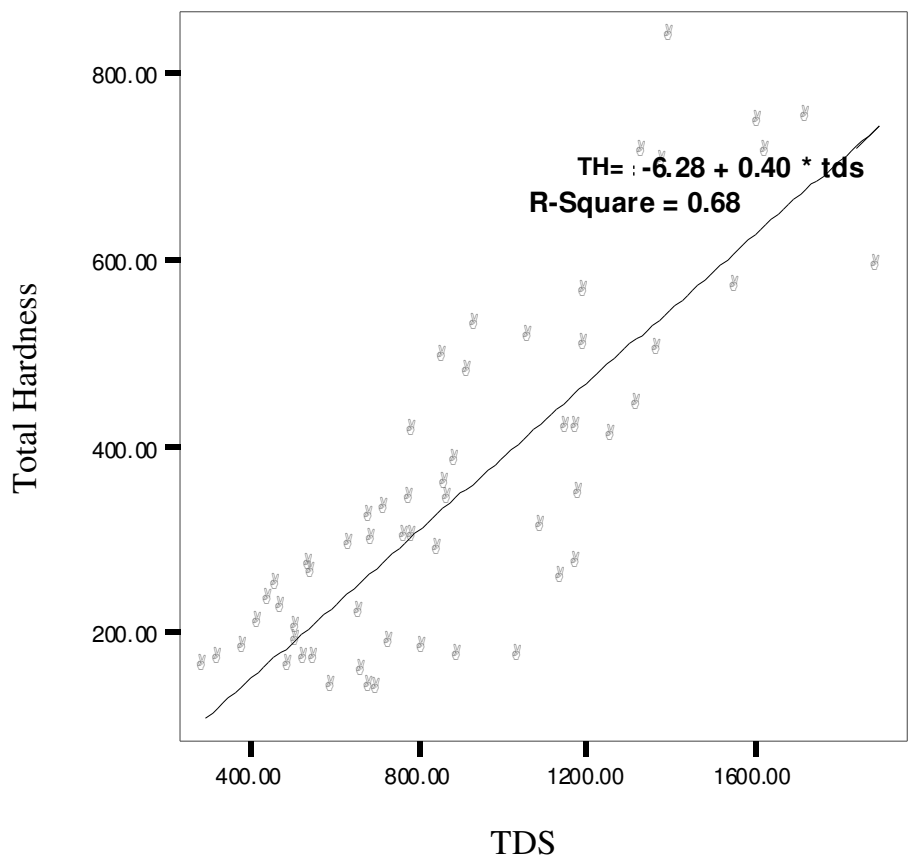

Figure 3. Correlation between total dissolved solids and total hardness

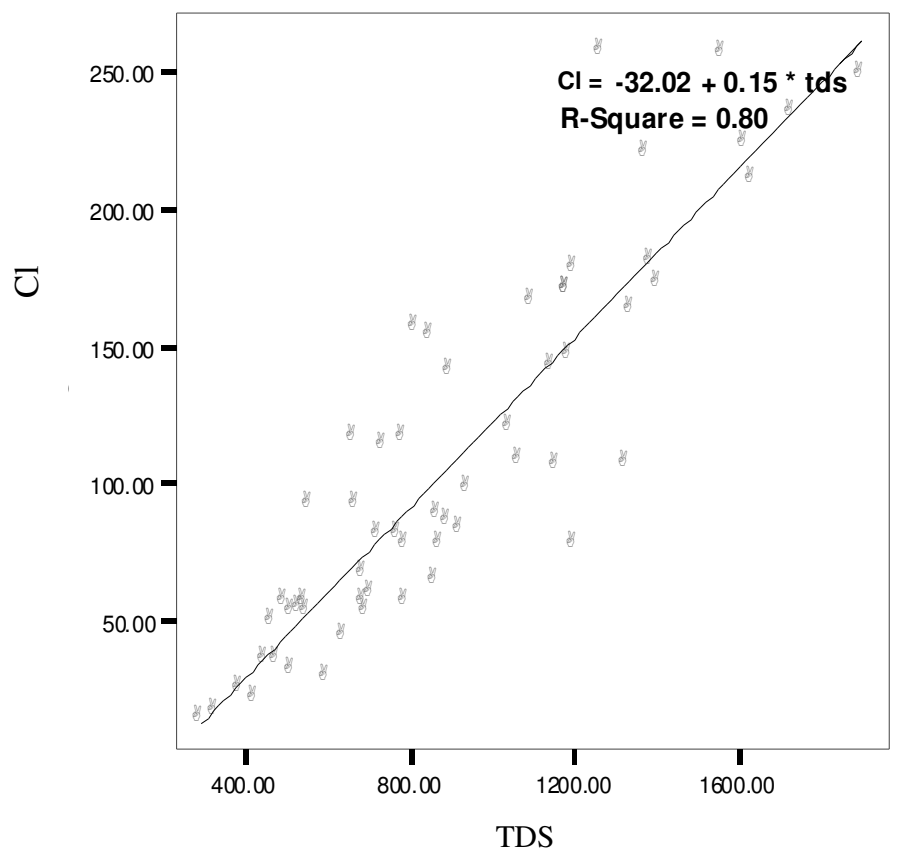

Figure 4. Correlation between total dissolved solids and chloride. 


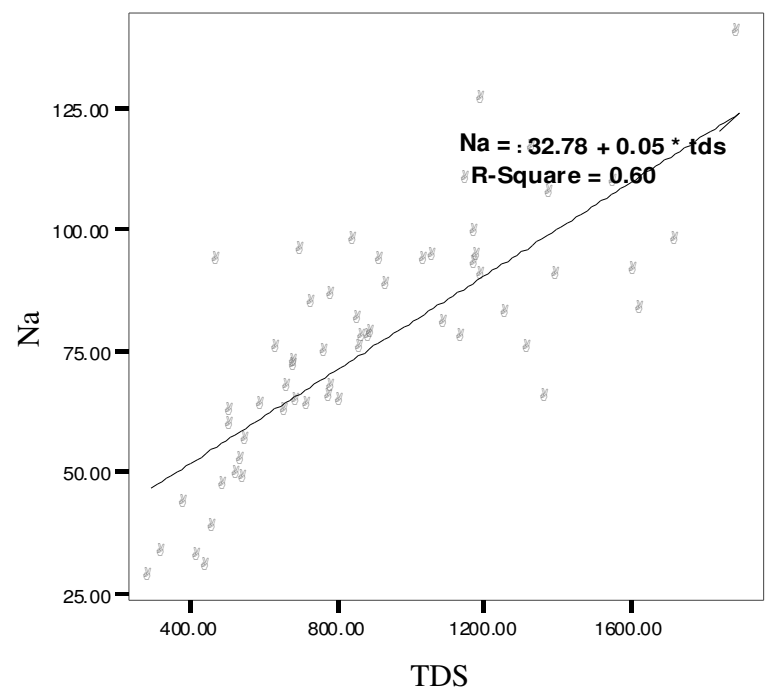

Figure 5. Correlation between total dissolved solids and sodium

Table 4 represents the factor loading which were used to measure the correlation between variable and factors. Component loading higher than 0.6 is taken into consideration as suggested by Mahloch ${ }^{24}$ and Mazlum and Mazlum ${ }^{25}$. The components with larger variance are more desirable since they give more information about the data. The highest factor loading of TDS and EC is 0.943 and 0.925 , respectively indicating the strong relationship between these two variables (Table 4), which is further supported by regression analysis as $r=0.91$ and cluster analysis (Dendrogram) as shown in Figure 7.

The concentration of salinity, Cl, TDS and EC show high positive loading $(0.879-0.943)$ and the concentration of $\mathrm{CO}_{2}, \mathrm{Na}$ and hardness have moderate positive loading (0.653 -0.759) in the first component. The second component contain high positive loading of DO and $\mathrm{Mg}$. The third component is governed by $\mathrm{Ca}$ and $\mathrm{SiO}_{2}$ whereas fourth component exhibit only $\mathrm{K}$ ions. On the basis of the factor loading the first component can be established as "salt factor" as it contains EC and some important inorganic salts along with salinity ${ }^{15}$.The first component is associated with a combination of various hydrogeochemical processes that contribute to enrich more mineralized water (high value of TDS), as suggested by Rao et ll $^{3}$ and $\mathrm{Hem}^{26}$. The enrichment of $\mathrm{Na}$ and $\mathrm{Cl}$ ions in groundwater is due to the interaction of water with rocks and secondly the association of TDS with higher concentrations of $\mathrm{Na}$ and $\mathrm{Cl}$ ions. This indicates anthropogenic activities such as discharge of sewage in open unlined earthen canals and pits, which support the sewage to percolate and finally mixes with groundwater. It can be understood that domestic wastes percolate into soil from where it mixes with groundwater. Component first supports the contamination in groundwater from human and animal wastes. Similar observations have also been reported by Chettri and $\mathrm{Smith}^{27}$, Fisher and Mullican ${ }^{28}$, Rao et. al $l^{3}$. The concentration of $\mathrm{HCO}_{3}$ in the groundwater is the result of the reaction of soil $\mathrm{CO}_{2}$ with the dissolution of silicate minerals. According to Rao et. al. ${ }^{3}$ the mineral dissolution during water-soil and water-rock interactions depends upon the amount of $\mathrm{CO}_{2}$ which originates from $\mathrm{H}_{2} \mathrm{CO}_{3}$. The negative loading of $\mathrm{pH}$ suggest that the decrease of $p \mathrm{CO}_{2}$ and $\mathrm{H}_{2} \mathrm{CO}_{3}$ values during out gassing of $\mathrm{CO}_{2}$ results in an increase of $\mathrm{pH}$, when the level of $\mathrm{CO}_{2}$ decreases there is sharp rise in $\mathrm{pH}$ value which shift the water towards alkaline side and the concentration of $\mathrm{HCO}_{3}$ increases. Minerals of the bed rock are subjected to weathering and subsequently affected by leaching, which contribute 
dissolved salts to groundwater, resulting in an increase in TDS, EC and hence water salinity ${ }^{3}$. Second component show high positive loading of DO and $\mathrm{Mg}$. High loading of $\mathrm{Mg}$ ions is related to the weathering of ferro magnesium mineral and anthropogenic sources as also suggested by Rao et.al. ${ }^{3} ; \mathrm{Hem}^{26}$; Zhang et al. ${ }^{29}$ and Satyanarayana and Periakali ${ }^{30}$. Third component is controlled by $\mathrm{Ca}$ and $\mathrm{SiO}_{2}$ relates to weathering of feldspar and silicate rocks. Fourth component shows association between $\mathrm{HCO}_{3}$ and $\mathrm{K}$. It is interesting to note that the eigen values for the second and third components are approximately same (1.62 and 1.52), indicating that their relative effects are similar.

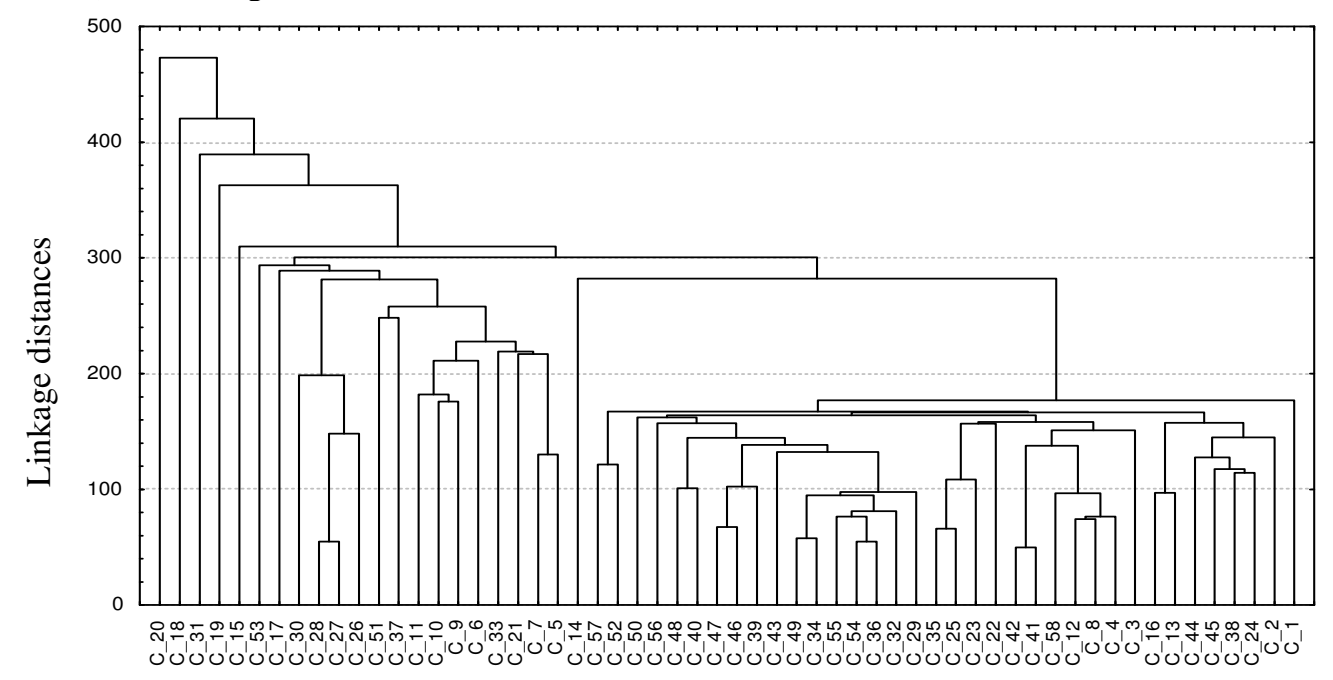

Euclidean distances

Figure 6. Dendrogram of the location of 58 cases using single linkage

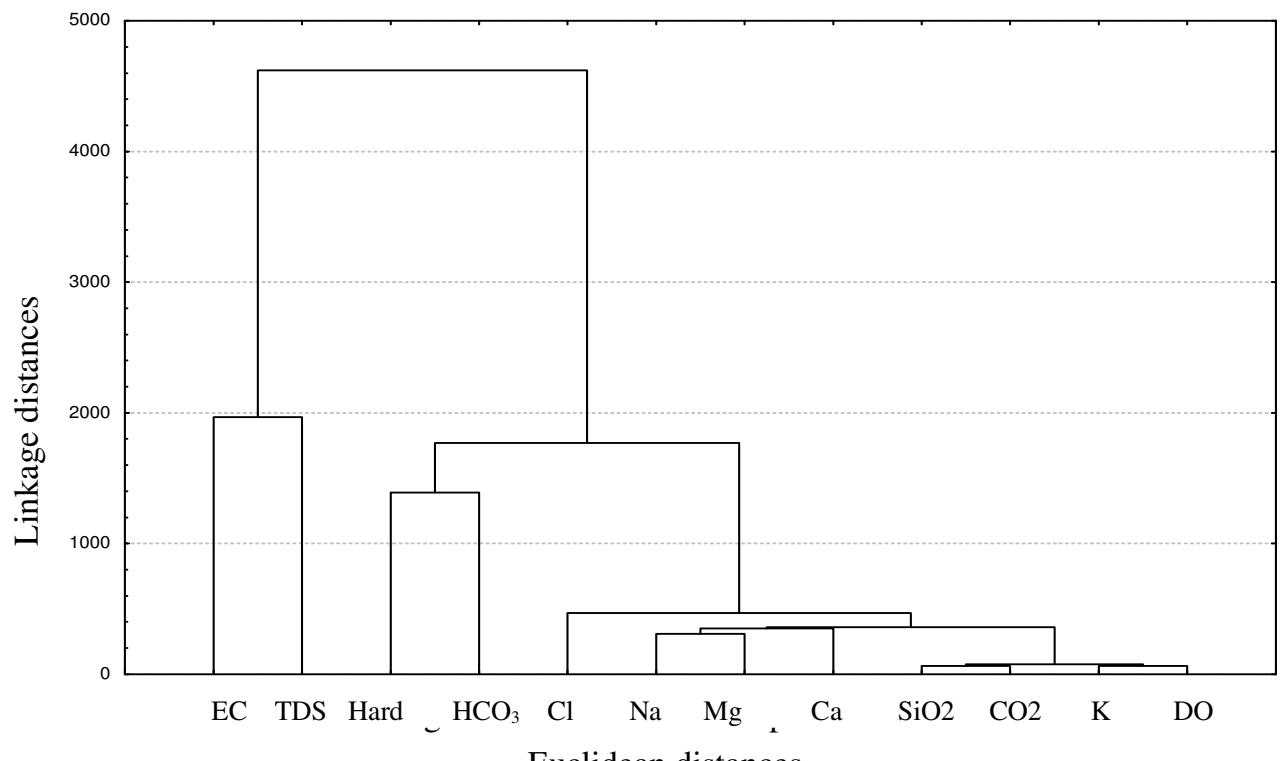

Euclidean distances

Figure 7. Dendrogram of the 12 chemical parameters of 58 cases. 
The dendrogram of sampling stations produced four major groupings (Figure 6). The dendrogram shows that the association between cases (sampling stations) $41-42 ; 27-28 ; 36$ $54 ; 34-59 ; 46-47 ; 40-48 ; 13-16 ; 52-57$ and $5-7$ is more significant. The first cluster group shows close association between 41 and 42 with bonds to station $58,12,8$, and 4 and to a lesser degree, station 3. Second group of association is between SS 27 and 28 which bound with SS 26 and 30 with lesser degree of association. There is a close association between 34 and 49 which resembles with SS 36 and 54, and this cluster constitute third group. The fourth group marked by the association between sampling station 25 and 35, showing affinity with group first. Sampling station 18, 19, 20 and 31 shows association with rest of the sampling stations at lesser degree as linkage distance is from 300 to 500 .

Another dendrogram of the 12 indexes based on the cluster analysis is depicted in Fig 7. On the basis of dendrogram of all 12 indexes can be grouped into four main clusters. First cluster group shows close association between $\mathrm{SiO}_{2}, \mathrm{CO}_{2}, \mathrm{~K}$ and DO. This group is further associated with group second to a lesser degree, having $\mathrm{Na}, \mathrm{Mg}$ and $\mathrm{Ca}$ indexes. Group third and fourth shows the close association between hardness-bicarbonate and EC -TDS. These indexes have high values in most of the sampling stations. These findings corroborates with the results of correlation analysis and cluster analysis.

\section{Conclusion}

In general the groundwater of the Moradabad city is alkaline in nature and hard, but at some places the water is relatively soft and falls within the safety limits as prescribed by WHO and Indian Standards. The concentration of TDS, EC, TH, $\mathrm{Ca}, \mathrm{Mg}, \mathrm{Na}, \mathrm{HCO}_{3}$ and $\mathrm{Cl}$ at most of the sampling stations exceeds the safety limits for drinking water. Computational analysis of the data set of hydrochemical constituents in the groundwater suggests that the aquifer (TDS) is mainly controlled by $\mathrm{Cl}, \mathrm{TH}, \mathrm{Na}$, salinity and $\mathrm{EC}$. There is a strong positive relationship between TDS-EC; TDS-Cl; TDS-TH and TDS-Na. The data were analyzed for factor analysis and first four components are chosen, which contribute $77.38 \%$ of the total variance. Dendrogram of the 58 cases and 12 variables are plotted and grouped into four main clusters.

\section{Acknowledgement}

The author (JKP) is thankful to DST, Government of India for the financial support. The authors are also thankful to Prof. S.D. Bhatt, Department of Zoology, Kumaun University Campus, Almora for his constant encouragement and Dr. V.K. Tyagi, Department of Zoology, Hindu College, Moradabad for his valuable suggestions.

\section{References}

1. Rao NS and Devedas D J, Environmental Geology, 2003, 45, 243-251.

2. Rao SM and Mamatha P, Curr Sci, 2004, 87, 7, 942-947

3. Rao NS, Devedas D J and Rao KVS, Environmental Geosciences, 2006, 13, 239-259.

4. Mathur S M, Physical Geology of India. National Book Trust, New Delhi, 1991.

5. APHA, AWWA, WEFC, Standard Methods for the Examination of water and Waste water. APHA, Washington, D.C. 200005, 2002,

6. Trivedy $\mathrm{R}$ K, Goel $\mathrm{P} \mathrm{K}$ and Trisal $\mathrm{C}$ L, Practical methods in Ecology and Environmental Science. Environmental Pub., Karad, 1986, pp 340.

7. Golterman H, Clymo R S and Ohrstad M A M, Methods for physical and chemical analysis for fresh water. I.B.P. Handbook No.8, Blackwell, 1978.

8. Goldman C R and Horne A J, Limnology, McGraw Hill Inc. Book Co. Tokyo, 1983, pp 371. 
9. Welch P S, Limnological Methods, Narendra Publishin House, New Delhi. 2003, pp,371, (Indian Reprint).

10. Weaver M C J, Cave L and Talma A S, Groundwater Sampling: A Comprehensive guide for sampling method, WRC Report No TT 303/07, 2007, pp 168.

11. SchoerJ C, Environ. Technol. Lett, 1985, 6, 189-202.

12. Buckley D E and Winters G V, Can. J. Earth Sci., 1992, 29, 2617-2639.

13. Padro R E B, Castrillejo Y, Valasco M A and Vaga M, Anal. Lett, 1993, 26, 1719-1739.

14. Kaiser H F, Psychometrika, 1958, 23, 187-200.

15. Praus P, Water SA, 2005, 417-422.

16 Kowalkowski T, Zbytniewski R, Szpejna J and Buszewski B, Water Res., 2006, 49, 744-752.

17 Alberto WD, Delpilar D M, Valaria A M, Fabianaps, Cecilia HA AND DE Los Angels BM, Water Res., 2001, 35, 2881-2894.

18. Zeng X and Rasmussen T C, J Environ Qual, 2005, 34 1981-1991.

19 Browne M W, Psychometrika, 1968, 33, 267-334.

20. Linn R L, Psychometrika, 1968, 33, 37-71.

21. Tucker L R, Koopman R F and Linn R L, Psychometrika, 1968, 34, 421-459.

22. Hakstain A P, Roger W D and Cattel R B, Multiv. Behav. Res, 1982, 17, 193-219.

23. Kaiser H F, Edu. Psychol.Meas, 1960, 20, 141-151.

24. Mahloch, J. Environ.Eng Div. Amer. Soc. Civil Eng.1974,100 No. EE5, 1119-1132.

25. Mazlum N, OZER A and Mazlum, Turkish J. Eng. Env. Sci., 1999, 23, 19-26.

26. Hem J D, Study and interpretation of the chemical characteristics of natural water. Scientific Publisher, Jodhpur, India, 1991, pp 263.

27. Chettri M and Smith, Hydrogeology Journal, 1995, 3, 71-76.

28. Fisher R S and Mulican W F, Hydrogeology Journal,1997, 5, 4-16.

29. Zhang J, Huang Wwletolle R and Jusserand C, Journal of Hydrology, 1995, 168, 173-203.

30. Satyanarayan M and Periakali, Journal of Geological Society of India, 2003, 62 63-73. 


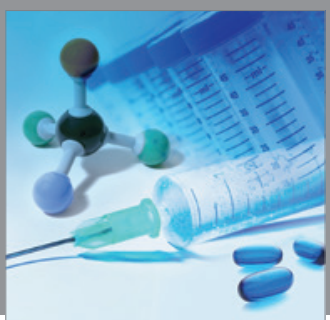

International Journal of

Medicinal Chemistry

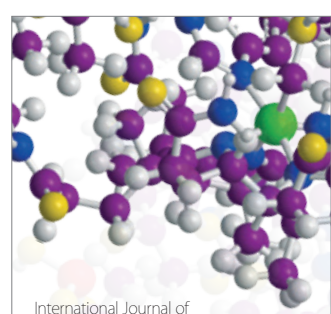

Carbohydrate Chemistry

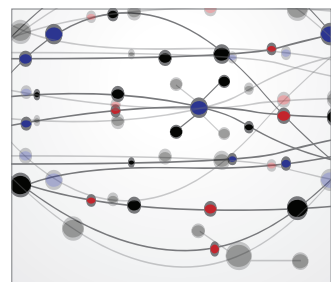

The Scientific World Journal
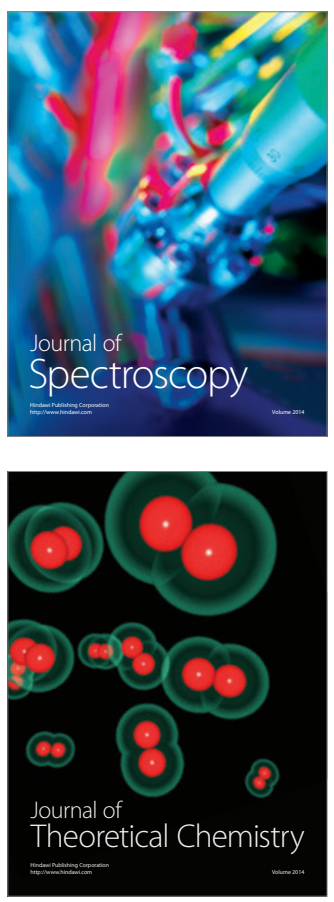
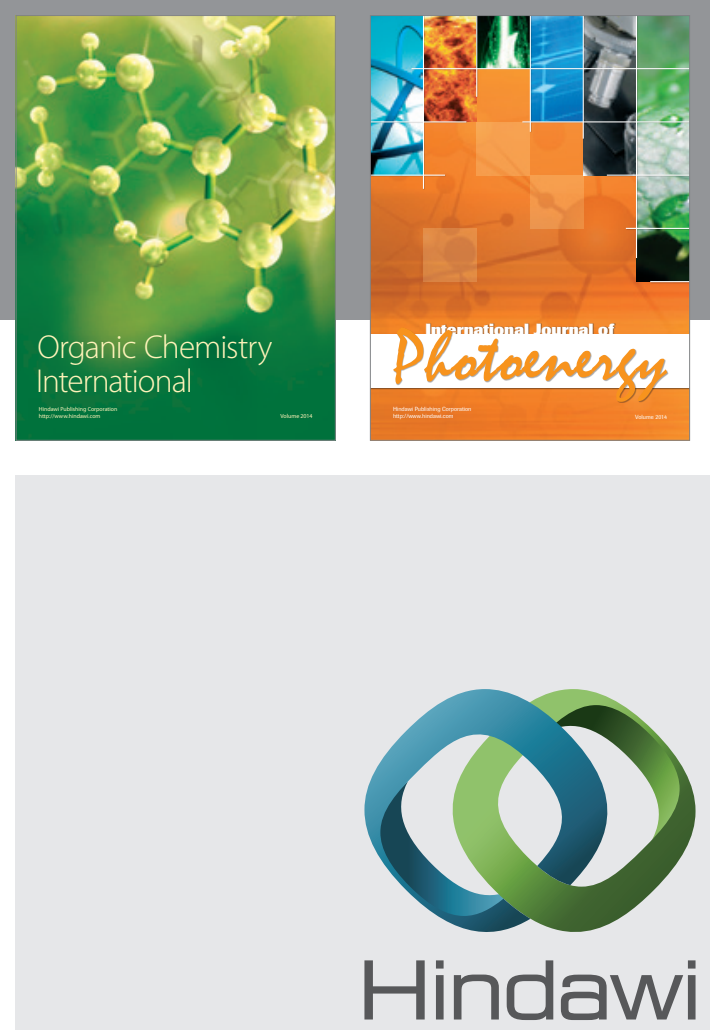

Submit your manuscripts at

http://www.hindawi.com
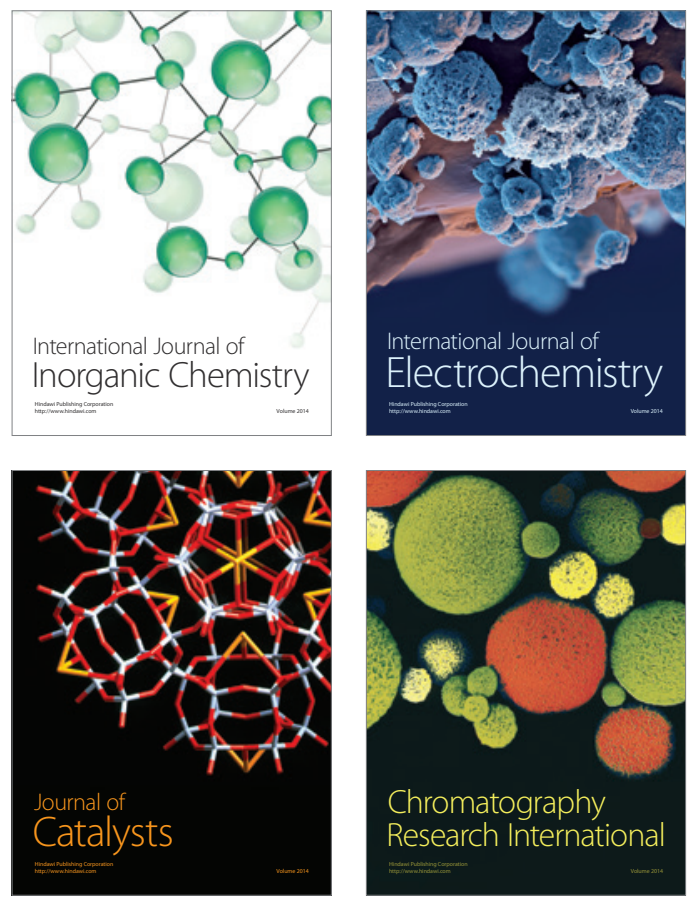
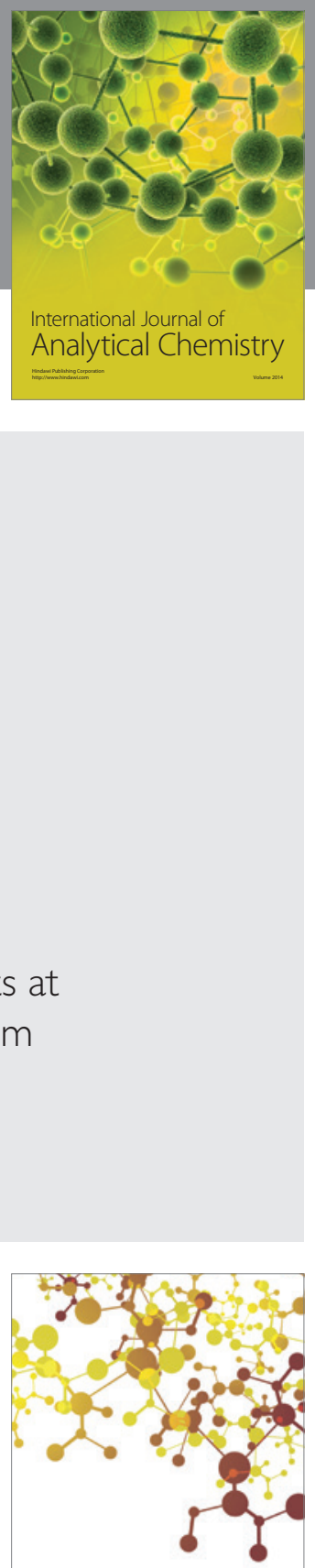

Journal of

Applied Chemistry
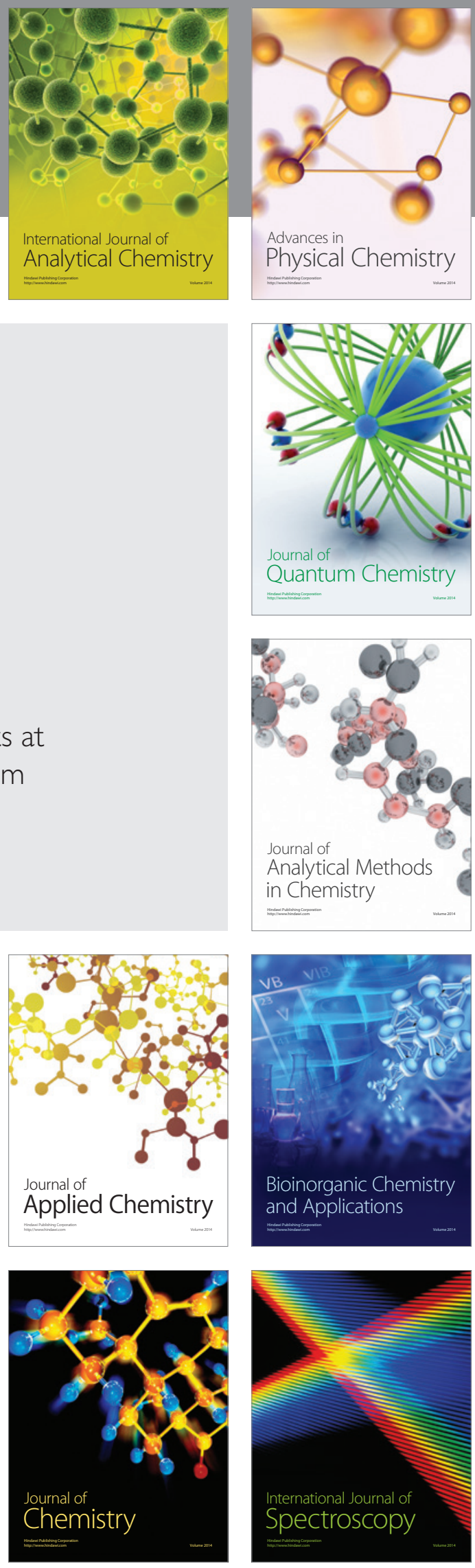